\title{
Genetic variation of Tunisian Myrtus communis L. (Myrtaceae) populations assessed by isozymes and RAPDs
}

\author{
Chokri MessAOud ${ }^{\mathrm{a}}$, Makrem AFIF ${ }^{\mathrm{a}}$, Abdennacer BouliLA ${ }^{\mathrm{a}}$, Mohamed Nejib REJEB $^{\mathrm{b}}$, \\ Mohamed BousSAID ${ }^{\text {* }}$ \\ a National Institute of Applied Science and Technology, Department of Biology, Laboratory of Plant Biotechnology, \\ Centre Urbain Nord, BP 676, 1080 Tunis Cedex, Tunisia \\ ${ }^{\mathrm{b}}$ National Institute of Research in Agricultural Engineering, Water and Forests, BP 10, Ariana- 2080, Tunisia
}

(Received 21 September 2006; accepted 16 July 2007)

\begin{abstract}
The genetic variation of six Tunisian Myrtus communis L. (Myrtaceae) populations was assessed using nine isozymes coding for 17 putative loci and 79 RAPD markers, amplified by five decamer random primers. The analysed populations belonged to three bioclimatic zones (lower humid, sub-humid and upper semi-arid). A high genetic diversity within populations was detected both by isozymes and RAPDs. The level of variation differed according to bioclimate. Populations collected from sub-humid bioclimate showed more polymorphism than those grown in the upper semi-arid zone. For all populations, the genetic diversity revealed by RAPDs was more pronounced than that detected with isozymes. A high differentiation among populations related to bioclimate and geographic distance was revealed by both methods. Population's structure based on RAPD markers was more concordant with bioclimatic zones in comparison with isozymes. Differentiation between ecological groups was higher than that revealed within groups. Conservation programs should take into account the level of genetic diversity within population revealed by the two complementary classes of markers according to bioclimate.
\end{abstract}

Myrtus communis / RAPDs / isozymes / genetic diversity / Tunisia

Résumé - Variabilité génétique des populations tunisiennes de Myrtus communis L. (Myrtaceae) estimée par des marqueurs isoenzymatiques et moléculaires (RAPD). La variabilité génétique de six populations tunisiennes de Myrtus communis L. (Myrtaceae) a été estimée à l'aide de neuf systèmes isoenzymatiques contrôlés par 17 loci et 79 marqueurs RAPD amplifiés par cinq amorces. Les populations analysées appartiennent à trois étages bioclimatiques différents : humide inférieur, sub-humide et semi-aride supérieur. Une diversité génétique intrapopulation importante a été détectée. Le niveau de polymorphisme varie selon le bioclimat. Les populations du sub-humide sont plus polymorphes. Pour l'ensemble des populations, la diversité génétique révélée par les RAPDs est plus importante que celle détectée par les isozymes. Une forte différenciation entre les populations, selon le bioclimat et l'éloignement géographique, a été révélée par les deux méthodes. La structuration des populations selon les marqueurs RAPD concorde mieux avec le bioclimat. La différenciation entre les populations appartenant à des groupes écologiques différents est plus importante que celle entre populations d'un même groupe. Les programmes de conservation de l'espèce doivent tenir compte aussi bien du degré de la diversité génétique intrapopulation révélé par les deux types de marqueurs que du bioclimat.

Myrtus communis / RAPDs / isozymes / diversité génétique / Tunisie

\section{INTRODUCTION}

Myrtus communis L. (myrtle) (Myrtaceae) is an evergreen shrub which grows mainly in Mediterranean Quercus suber $\mathrm{L}$. and Quercus faginea Lamk. forests [36,41], reproducing both by seeds and suckers [4]. The species is exploited in traditional medicine as astringent, antiseptic and balsamic $[5,10]$. Leaves and fruits were used against respiratory and urinary diseases [5,9]. Essential oil extracted from these organs is rich in $\alpha$-pinene and 1,8 -cineole $[33,47]$. The demand for this plant is increasing in pharmaceutic, perfumery and food industries $[34,35]$. In Sardinia, myrtle berries and leaves are largely used for liquor production $[2,15]$.

In Tunisia, the species grows wild in different bioclimatic zones extending from the upper semi-arid to the lower hu-

* Corresponding author: mohamed.boussaid@insat.rnu.tn mid, in three geographic areas [33]. In the North West of the country, populations grow on acid soils with an annual rainfall ranging from 1000 to $1500 \mathrm{~mm}$. The associated species are mainly Quercus suber L., Q. faginea Lamk., Arbutus unedo L., Erica arborea L., Rubus ulmifolius Schott., Hedera helix L., Halimium halimifolium (L.) Willk., Pistacia lentiscus L., Smilax aspera L., Cistus monspeliensis L. and Cytisus triflorus L'Hérit. In the Cap-Bon, the species occurs in isolated populations with a low size, growing on calcareous or acid soils with an annual rainfall ranging from 500 to $600 \mathrm{~mm}$. Main species associated to Myrtus communis L. are Pinus halepensis Mill., Quercus coccifera L., Ceratonia siliqua L., Juniperus phoenicea L. Phillyrea angustifolia L., Pistacia lentiscus L., Cistus monspeliensis L., C. salviifolius L. and Rubus ulmifolius Schott. In the Tunisian Dorsal, the species is endangered and represented by scattered individuals growing on 
calcareous soil, along profound ravines and ephemeral rivers. The annual rainfall varies from 350 to $450 \mathrm{~mm}$. Myrtus communis L. is accompanied by Pistacia lentiscus L., Ceratonia siliqua L., Phillyrea angustifolia L., Rosmarinus officinalis L., Nerium oleander L., Rubus ulmifolius Schott. and Calycotome villosa (Poiret) Link.

In the three areas, populations are more and more disturbed and fragmented as a result of an increasing clearing, overgrazing and overexploitation. Myrtle habitat fragmentation reduced genetic diversity of the species, increased inbreeding level and led to a rapid differentiation between populations. The loss of genetic diversity affected population's evolution and reduced their future adaptation to environmental changes $[8,11,17]$. Knowledge of the level of genetic diversity within and among populations constitutes the first step to understand their subsequent evolution and to elaborate adequate preservation programs $[22,50]$.

Isozymes are powerful tools for genetic diversity analysis and conservation biology $[19,49]$. They are codominant, and assumed to be neutral. However, this assumption is not always held $[7,26]$. Yet nowadays, molecular markers such as RAPDs, RFLPs, AFLPs, SSRs are used to assess population genetic variation. RAPD markers (Random Amplified Polymorphic DNA) are selectively neutral, involve a large number of loci and cover a larger part of the genome. They also provide more valuable information into population differentiation and help to elaborate efficient conservation strategies [16, 18, 23, 42]. However, most RAPD loci are assumed to possess only two alleles and segregate as dominant markers, leading to an underestimation of the genetic diversity $[30,45]$.

Because isozymes and RAPDs, each has advantages and limitations to assess genetic variations their joint use is necessary to better estimatethe genetic diversity and population structure in order to avoid wrong conclusions for rational use of species $[28,46]$.

In this paper, we investigate the genetic variation of six natural Tunisian myrtle populations growing in different bioclimatic regions, using both isozymic and RAPD markers. This study constitutes a complementary to that previously reported on Tunisian myrtle population's structure based on isozymes [32], for further global information in order to elaborate improvement and conservation programs.

We address the following questions: (1) What is the pattern of genetic variation within and among populations based on each marker? (2) Is population differentiation related to bioclimate? (3) Do isozymic andRAPD markers provide similar conclusions? (4) What is the implication of the detected genetic variation for conservation strategies?

\section{MATERIALS AND METHODS}

\subsection{Surveyed populations and sampling}

Six Tunisian Myrtus communis populations (Fig. 1 and Tab. I) were sampled to assess their genetic variation. These populations belonged to lower humid, sub-humid and upper semi-arid bioclimatic zones $[12,36]$. Plants, in each population, were sampled at

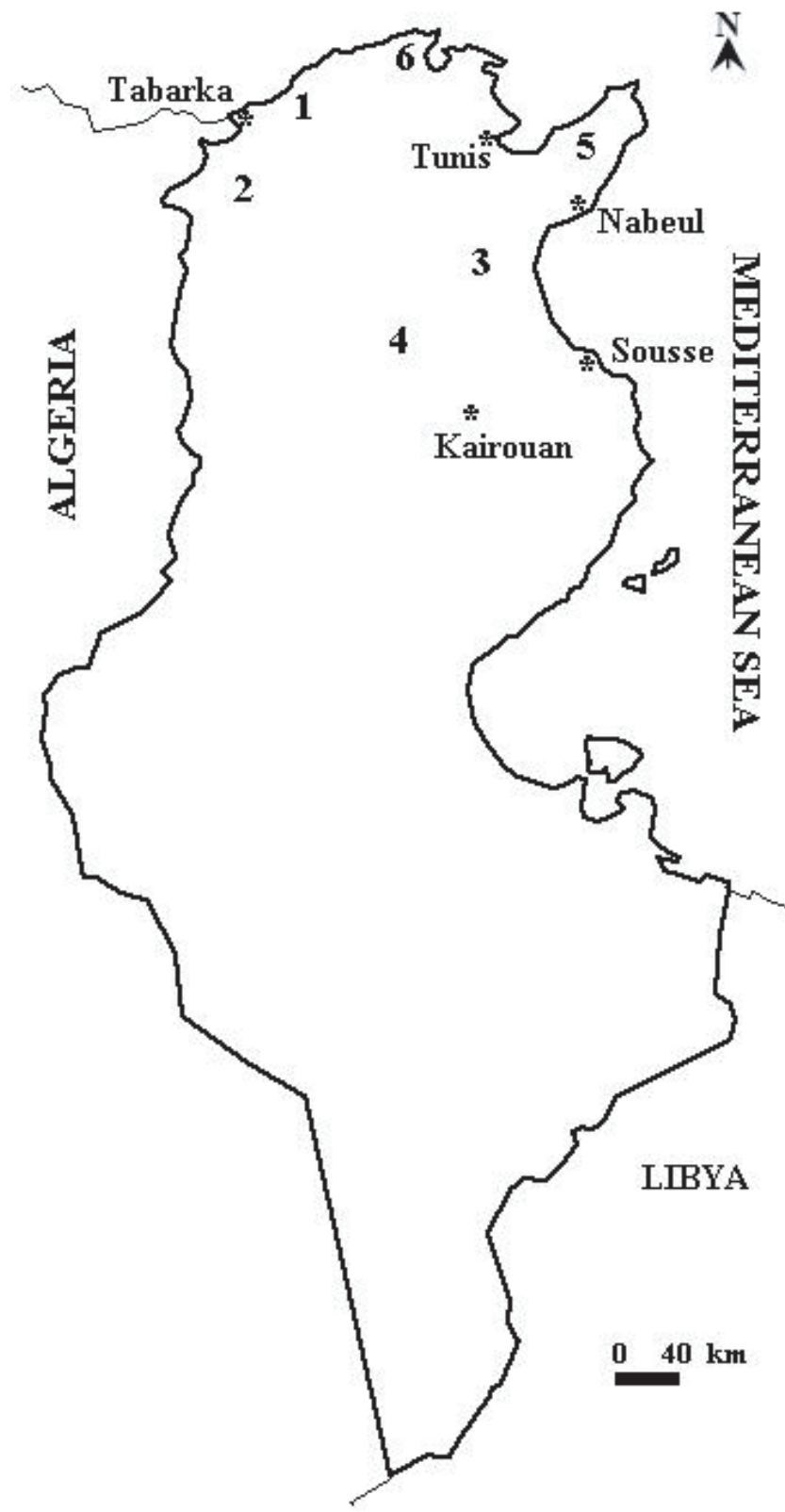

Figure 1. Map of Tunisia: Geographic location of the six populations of Myrtus communis analysed. 1,2, 3, 4, 5 and 6: populations. * Great towns.

distances exceeding $20 \mathrm{~m}$ to avoid multiple sampling from the same parent. Twenty and seven to eight plants per population were used for isozyme and RAPD analyses, respectively. Analysed organs were leaves collected from each individual.

\subsection{Isozyme electrophoresis}

Proteins were extracted from $350 \mathrm{mg}$ young leaves ground in $1 \mathrm{ml}$ extraction buffer with liquid nitrogen. The extraction method, the composition of gel and electrode buffers were reported in Messaoud et al. [32]. We used horizontal $13 \%$ starch gel electrophoresis 
Table I. Main ecological traits for the six Tunisian Myrtus communis populations analyzed.

\begin{tabular}{|c|c|c|c|c|c|c|c|c|}
\hline Population code & Location & Latitude & Longitude & Bioclimatic zone* & Geographic region & $\mathrm{Q}_{2}$ & Winter variant & Altitude (m) \\
\hline 1 & Tamra & $37^{\circ} 05^{\prime} \mathrm{N}$ & $8^{\circ} 65^{\prime} \mathrm{E}$ & Lower Humid & North West & 144.24 & $\begin{array}{c}\text { Cool } \\
1<\mathrm{m}<3^{\circ} \mathrm{C}\end{array}$ & 440 \\
\hline 2 & Fernena & $36^{\circ} 42^{\prime} \mathrm{N}$ & $8^{\circ} 48^{\prime} \mathrm{E}$ & Lower Humid & North West & 144.24 & $\begin{array}{c}\text { Temperate } \\
3<\mathrm{m}<4.5^{\circ} \mathrm{C}\end{array}$ & 300 \\
\hline 3 & $\begin{array}{l}\text { Zaghouan Jebel } \\
\text { mountain }\end{array}$ & $36^{\circ} 26^{\prime} \mathrm{N}$ & $10^{\circ} 46^{\prime} \mathrm{E}$ & Upper Semi-arid & Tunisian Dorsal & 55.44 & $\begin{array}{c}\text { Temperate } \\
3<\mathrm{m}<4.5^{\circ} \mathrm{C}\end{array}$ & 300 \\
\hline 4 & $\begin{array}{c}\text { Bargou Jebel } \\
\text { mountain }\end{array}$ & $36^{\circ} 05^{\prime} \mathrm{N}$ & $9^{\circ} 30^{\prime} \mathrm{E}$ & Upper Semi-arid & Tunisian Dorsal & 45.70 & $\begin{array}{c}\text { Temperate } \\
3<\mathrm{m}<4.5^{\circ} \mathrm{C}\end{array}$ & 865 \\
\hline 5 & $\begin{array}{c}\text { Abdrrahman Jebel } \\
\text { mountain }\end{array}$ & $36^{\circ} 40^{\prime} \mathrm{N}$ & $10^{\circ} 46^{\prime} \mathrm{E}$ & Sub-humid & Cap Bon & 65.61 & $\begin{array}{c}\text { Temperate } \\
3<\mathrm{m}<4.5^{\circ} \mathrm{C}\end{array}$ & 420 \\
\hline 6 & Bizerte & $37^{\circ} 15^{\prime} \mathrm{N}$ & $9^{\circ} 48^{\prime} \mathrm{E}$ & Sub-humid & North East & 88.70 & $\begin{array}{c}\text { Hot } \\
7<\mathrm{m}<10.5^{\circ} \mathrm{C}\end{array}$ & 50 \\
\hline
\end{tabular}

* Bioclimatic zones were defined according to Emberger's $\mathrm{Q}_{2}$ pluviothermic coefficient [12]. $\mathrm{Q}_{2}=2000 \mathrm{P} /\left(\mathrm{M}^{2}-\mathrm{m}^{2}\right)$ where $\mathrm{P}$ is the mean of annual rainfall $(\mathrm{mm}), \mathrm{M}(\mathrm{K})$ is the mean of maximal temperatures for the warmest month (June) and $\mathrm{m}(\mathrm{K})$ is the mean of minimum temperatures for the coldest month (February). $\mathrm{Q}_{2}$ values were calculated for each site using P, M and $\mathrm{m}$ values for the period 1953-2003. Data have been provided by the Tunisian National Institute of Meteorology.

to screen 9 enzyme systems: Leucine aminopeptidase (Lap, E.C. 3.4.11.1), Alcohol dehydrogenase (Adh, E.C. 1.1.1.1), Glutamate oxaloacetate transaminase (Got, E.C. 2.6.1.1), Esterase (Est, E.C. 3.1.1.), Isocitrate dehydrogenase (Idh, E.C. 1.1.1.42), Malate dehydrogenase (Mdh, E.C. 1.1.1.37), Phospho-glucomutase (Pgm, E.C. 2.7.5.1), 6-Phosphogluconate dehydrogenase (6-Pgd, E.C. 1.1.1.44) and Phosphoglucoisomerase (Pgi, E.C. 5.3.1.9). Electrophoresis was carried out at $4{ }^{\circ} \mathrm{C}$ for $8 \mathrm{~h}(50 \mathrm{~mA})$. Staining isozymes protocols followed standard methods as reported by Goodman et al. [20] and Weeden and Wendel [51].

\subsection{RAPD procedure}

\subsubsection{DNA extraction}

Young leaves $(0.5 \mathrm{~g})$ were powdered in liquid nitrogen, mixed with $700 \mu \mathrm{L}$ CTAB extraction buffer and $100 \mathrm{mg}$ PVP 40000. Samples were then incubated at $65{ }^{\circ} \mathrm{C}$ for $30 \mathrm{~min}$ with slow shaking every $10 \mathrm{~min}$. Subsequently the mixture was treated twice with $700 \mu \mathrm{L}$ chloroform-isoamyl alcohol (24:1) and centrifuged for $10 \mathrm{~min}$ at $12000 \mathrm{rpm}$. DNA precipitation was performed following the method described by Lodhi et al. [29]. The quality of the DNA was estimated on an agarose gel $(0.8 \%)$ stained with ethidium bromide.

\subsubsection{Primers and PCR conditions}

Twenty RAPD primers (kit OPJ, Genset Oligos, Promega) were tested. After optimising the PCR conditions, five RAPD primers (OPJ04, OPJ08, OPJ10, OPJ12 and OPJ20) were selected on the basis of the reproducibility and the polymorphism of the generated bands. The PCR reaction was performed in $25 \mu \mathrm{L}$ reaction volume containing $50 \mathrm{ng}$ DNA template, $2.5 \mu \mathrm{L}$ of $10 \mathrm{X}$ reaction buffer, 40 pmoles of primer, $200 \mu \mathrm{M}$ of each dNTP, $2.5 \mathrm{mM} \mathrm{MgCl} 2$ and $1.5 \mathrm{U}$ Taq polymerase (Promega). Mixture was overlaid with 1 drop of mineral oil and amplified in a Programmable Stuart Thermal Cycler (MaxiGene) under the following conditions: $94{ }^{\circ} \mathrm{C}$ for $2 \mathrm{~min}$, followed by 45 cycles at $94{ }^{\circ} \mathrm{C}$ for $30 \mathrm{~s}, 36{ }^{\circ} \mathrm{C}$ for $1 \mathrm{~min}$ and $72{ }^{\circ} \mathrm{C}$ for $2 \mathrm{~min}$. The last step was $72{ }^{\circ} \mathrm{C}$ for $10 \mathrm{~min}$ for final polymerase reaction. PCR products were separated by electrophoresis in $1.5 \%$ agarose gel at $120 \mathrm{~V}$ for $2 \mathrm{~h}$ in $1 \mathrm{X}$ TAE buffer $(\mathrm{pH} 8)$. Gel was stained with ethidium bromide, visualized under UV light and photographed with DOC PRINT Photo Documentation System. Molecular weights were estimated using a 200 pb DNA Promega ladder.

\subsection{Data analysis}

\subsubsection{Isozyme analysis}

Genetic variation within populations and within ecological groups (each group including populations from the same bioclimate) was assessed using the number of alleles per locus $(A)$, the effective number of alleles per locus $(A e)$, the percentage of polymorphic loci $\left(P_{i}\right)$ and the observed $(\mathrm{Ho})$ and expected $(\mathrm{He})$ heterozygosities. Calculation of $A, P_{i}, H o$ and $\mathrm{He}$ parameters were performed using BIOSYS software package [44]. The POPGENE program [56] was used to estimate $A e$ values. The comparison of $\mathrm{A}, \mathrm{Ae}, \mathrm{He}$ and $\mathrm{Ho}$ between ecological groups was performed using a variance analysis (ANOVA procedure) over all loci.

Departure from Hardy-Weinberg equilibrium was evaluated by Wright's inbreeding coefficient $\left(F_{I S}\right)$ [54] estimated over all loci according to Weir and Cockerham's estimates [52]. Significance of deficit or excess of heterozygotes were performed by randomizing alleles among individuals.

Differentiation among populations (all populations or populations within the same ecological group) or among groups was estimated by Wright's $F$-statistics $\left(F_{I T}, F_{S T}\right.$ and $\left.F_{I S}\right)$ [54] using the program FSTAT version 2.9 .3 [21]. $F_{I T}$ and $F_{I S}$ are the inbreeding coefficients in all populations and within population respectively. $F_{S T}$ indicates the level of differentiation among populations. Significance of F-statistics was tested after 1000 permutations.

Nei's unbiased genetic identity coefficients [37] were calculated for all pairs of populations. The data was then used to produce a dendrogram based on the unweighted pair group method with the arithmetic averaging algorithm (UPGMA).

\subsubsection{RAPD analysis}

RAPD bands amplified by each of the five primers were numbered sequentially in decreasing order according to the molecular weight. 
Table II. Genetic diversity within populations and within ecological groups assessed by isozyme and RAPD markers: mean number of alleles per locus $(A)$, effective number of alleles per locus $(A e)$, percentage of polymorphic loci $\left(P_{i}\right.$ and $\left.P_{r}\right)$, observed $(H o)$ and expected heterozygosities $(H e)$ and Shannon's diversity index $\left(H^{\prime}\right)$.

\begin{tabular}{|c|c|c|c|c|c|c|c|c|}
\hline & \multicolumn{6}{|c|}{ Isozyme } & \multicolumn{2}{|c|}{ RAPD } \\
\hline & $A$ & $A e$ & $P_{i} \%$ & $H o$ & $\mathrm{He}$ & $F_{I S}$ & $P_{r} \%$ & $H^{\prime}$ \\
\hline \multicolumn{9}{|c|}{ Population } \\
\hline 1 & $1.4(0.1)$ & $1.31(0.10)$ & 41.20 & $0.121(0.048)$ & $0.179(0.055)$ & $0.334^{* * *}$ & 49.37 & 0.442 \\
\hline 2 & $1.4(0.1)$ & $1.18(0.08)$ & 29.40 & $0.065(0.042)$ & $0.107(0.045)$ & $0.403^{* * *}$ & 56.96 & 0.482 \\
\hline 3 & $1.5(0.1)$ & $1.22(0.09)$ & 47.10 & $0.074(0.034)$ & $0.135(0.044)$ & $0.446^{* * *}$ & 50.63 & 0.435 \\
\hline 4 & $1.5(0.1)$ & $1.31(0.10)$ & 47.10 & $0.082(0.042)$ & $0.190(0.055)$ & $0.573^{* * *}$ & 53.16 & 0.470 \\
\hline 5 & $1.5(0.1)$ & $1.30(0.09)$ & 52.90 & $0.103(0.049)$ & $0.178(0.050)$ & $0.428^{* * * *}$ & 54.43 & 0.523 \\
\hline 6 & $1.5(0.1)$ & $1.35(0.11)$ & 47.10 & $0.135(0.050)$ & $0.195(0.057)$ & $0.310^{* *}$ & 46.84 & 0.422 \\
\hline Mean & $1.47(0.02)$ & $1.28(0.03)$ & 44.13 & $0.097(0.01)$ & $0.163(0.012)$ & $0.410^{* * * *}$ & 51.90 & $0.462(0.015)$ \\
\hline \multicolumn{9}{|c|}{ Bioclimatic zone } \\
\hline LH & $1.5(0.1) \mathrm{a}$ & $1.25(0.07) \mathrm{a}$ & 41.20 & $0.093(0.043) \mathrm{a}$ & $0.150(0.048) \mathrm{a}$ & $0.387^{* *}$ & 62.03 & $0.507(0.047) \mathrm{a}$ \\
\hline $\mathrm{SH}$ & $1.6(0.1) \mathrm{a}$ & $1.34(0.10) \mathrm{a}$ & 47.10 & $0.125(0.047) \mathrm{a}$ & $0.203(0.056) \mathrm{a}$ & $0.397^{* *}$ & 64.56 & $0.553(0.046) \mathrm{a}$ \\
\hline USA & $1.6(0.1) \mathrm{a}$ & $1.28(0.10) \mathrm{a}$ & 47.10 & $0.078(0.034) \mathrm{a}$ & $0.165(0.048) \mathrm{a}$ & $0.529^{* *}$ & 60.76 & $0.503(0.046) \mathrm{a}$ \\
\hline Mean & $1.57(0.03)$ & $1.29(0.02)$ & 45.13 & $0.099(0.020)$ & $0.173(0.033)$ & $0.433^{* * *}$ & 62.45 & $0.521(0.016)$ \\
\hline
\end{tabular}

Standard errors are in parentheses; ** significant at $P<0.01 ; * * *$ significant at $P<0.001 ; P_{i} \%=\left(\right.$ polymorphic loci $/$ total loci) $\times 100 ; \mathrm{P}_{r} \%=$ (polymorphic RAPD bands/total RAPD bands) $\times 100$; LH: lower humid, SH: sub-humid, USA: upper semi-arid.

Values with the same letter in column are not significantly different (ANOVA, $P>0.05$ ).

RAPD fragments with the same mobility were scored for band presence (1) or absence (0). Since RAPD markers are dominant, it was assumed that each band represented the phenotype at a single bi-allelic locus $[24,53]$.

Genetic diversity within populations was estimated using the percentage of polymorphic bands $P_{r} \%\left[P_{r} \%=\right.$ (polymorphic bands/total bands $\times 100)]$ and Shannon's $H^{\prime}$ index $\left[H^{\prime}=\left(-\Sigma \pi_{i} \log _{2} \pi_{i}\right) / \mathrm{L}, \pi_{i}\right.$ is the frequency of the $i$ th RAPD band in that population and $\mathrm{L}$ is the number of loci].

To compare Shannon's $H^{\prime}$ index between the three bioclimatic zones, a variance analysis (ANOVA procedure) over loci was used.

Genetic similarity between individuals was estimated using the Nei and Li's similarity coefficient [38]: $S_{x y}=2 m_{x y} /\left(m_{x}+m_{y}\right)$, where $m_{x y}$ is the number of bands shared by samples $x$ and $y$, and $m_{x}$ and $m_{y}$ are the number of bands in samples $x$ and $y$, respectively. Genetic distance $(D)$ was estimated using the complementary value of similarity coefficient: $D_{x y}=1-S_{x y}$. A cluster analysis (UPGMA), based on the similarity matrix between individuals, was used to ordinate relationships among individuals using Multi-Variate Statistical Package MVSP [27].

The genetic variation within and among populations or within and between bioclimatic zones was also estimated by the molecular variance analysis (AMOVA) [13], based on the genetic distances between individuals. $\Phi$-statistics: $\Phi_{\mathrm{ST}}$ (differentiation among populations), $\Phi_{\mathrm{CT}}$ (differentiation among ecological groups) and $\Phi_{\mathrm{SC}}$ (differentiation among populations within groups), were calculated. Significance of variance components and of $\Phi$-statistics were evaluated using permutations procedures. All analyses were performed using WINAMOVA program, version 1.55 [13].

The correlation between $\log _{10}$ of gene flow $(\mathrm{Nm})$ and $\log _{10}$ of geographic distance between pairs of populations was tested by the Mantel test [31] using the program zt [6]. $N m=\left[\left(1 / \Phi_{\mathrm{ST}}\right)-1\right] / 4$ [54], where $\Phi_{\mathrm{ST}}$ is the pairwise genetic distance between populations, calculated from AMOVA.

\subsubsection{Combined data analysis}

Population structure, based on both isozymic and RAPD markers, was estimated by an UPGMA cluster analysis performed on the similarity matrix calculated from the combination of allele (isozyme) and RAPD band frequencies data. Cluster analysis was carried out using Multi-Variate Statistical Package MVSP [27].

The relationship between isozyme and molecular genetic diversity parameters was tested by the calculation of the correlation coefficient (i) between the Shannon's index $\left(H^{\prime}\right)$ and the expected heterozygosity (He) for each population using Kendall's rank test [39], (ii) between pairwise $F_{S T}$ (isozyme) and $\Phi_{\mathrm{ST}}(\mathrm{RAPD})$ values. Significance of the correlation was evaluated by the Mantel test [31].

\section{RESULTS}

\subsection{Isozyme genetic diversity and population structure}

For all populations, the nine analysed enzymes were encoded by 17 putative loci [32]. Twelve (70.59\%) out of them were polymorphic (Lap-1, Pgm-1, Est-1, Got-1, Idh-1, Idh2, Pgi-2, Adh-2, 6Pgd-2, Mdh-1, Mdh-2 and Mdh-3). Allelic frequencies varied according to bioclimate [32]. Pgd-2b and Got-1a were not detected in populations of the lower humid bioclimate. Adh-2a was not revealed in the upper semi-arid. Pgi-2a was detected only in some populations from the subhumid and the lower humid.

Levels of genetic diversity varied according to populations (Tab. II). The average number of alleles per locus $(A)$ was 1.47 (from 1.4 for populations 1 and 2 to 1.5 for populations 3,4 , 5 and 6). The effective number of alleles per locus $(A e)$ varied from 1.18 (population 2) to 1.35 (population 6 ). The percentage of polymorphic loci $\left(P_{i}\right)$ ranged between $29.4 \%$ (population 2, Fernena) to $52.9 \%$ (population 5, Abderrahman Jebel 
Table III. $F$-statistics $\left(F_{I T}, F_{S T}, F_{I S}\right)$ calculated for all populations, populations within the same bioclimate and between bioclimates.

\begin{tabular}{lccc}
\hline & $F_{I T}$ & $F_{S T}$ & $F_{I S}$ \\
\hline All populations (all polymorphic loci) & $0.657(0.106)^{* * *}$ & $0.414(0.097)^{* * *}$ & $0.410(0.138)^{* * *}$ \\
\hline Within bioclimatic zone & & & \\
LH & $0.405(0.208)^{* * *}$ & $0.077(0.047)^{n s}$ & $0.348(0.205)^{* * *}$ \\
SH & $0.425(0.165)^{* * *}$ & $0.093(0.043)^{n s}$ & $0.364(0.169)^{* * *}$ \\
USA & $0.532(0.152)^{* * *}$ & $0.032(0.015)^{\mathrm{ns}}$ & $0.516(0.157)^{* * *}$ \\
Among bioclimatic zone & $0.688(0.102)^{* * *}$ & $0.445(0.104)^{* * *}$ & $0.433(0.139)^{* * *}$ \\
(LH- SH-USA) & & \\
\hline
\end{tabular}

Standard errors are in parentheses; ns: not significant at $P>0.05$; *** significant at $P<0.001$.

Table IV. $F_{S T}$ (above diagonal) and $\Phi_{\mathrm{ST}}$ (below diagonal) values between pairs of populations analysed.

\begin{tabular}{lcccccc}
\hline Population & 1 & 2 & 3 & 4 & 5 & 6 \\
\hline 1 & - & $0.079^{\mathrm{ns}}$ & $0.616^{* * *}$ & $0.521^{* * *}$ & $0.047^{\mathrm{ns}}$ & $0.169^{*}$ \\
2 & $0.017^{\mathrm{ns}}$ & - & $0.679^{* * *}$ & $0.593^{* * *}$ & $0.105^{\mathrm{ns}}$ & $0.275^{*}$ \\
3 & $0.401^{* * *}$ & $0.412^{* * *}$ & - & $0.033^{\mathrm{ns}}$ & $0.557^{* * *}$ & $0.505^{* * *}$ \\
4 & $0.359^{* * *}$ & $0.368^{* * *}$ & $0.033^{\mathrm{ns}}$ & - & $0.458^{* * *}$ & $0.405^{* * *}$ \\
5 & $0.283^{* * *}$ & $0.275^{* * *}$ & $0.372^{* * *}$ & $0.379^{* * *}$ & - & $0.091^{\mathrm{ns}}$ \\
6 & $0.324^{* * *}$ & $0.365^{* * *}$ & $0.417^{* * *}$ & $0.403^{* * *}$ & $0.119^{* * *}$ & - \\
\hline
\end{tabular}

ns: Not significant; * significant at $P<0.05 ; * * *$ significant at $P<0.001$.

mountain) with a mean of $45.13 \%$. The averages of the observed $(\mathrm{Ho})$ and expected $(\mathrm{He})$ heterozygosities were 0.097 and 0.163 , respectively. A significant excess of homozygotes $\left(F_{I S}>0, P<0.01\right)$ was observed for all populations.

Within bioclimatic zones the average number of alleles per locus $(A)$ was 1.57 (1.5 to 1.6$)$, the effective number of alleles per locus $(A e)$ ranged from 1.25 to 1.34 , with an average of 1.29. The mean percentage of polymorphic loci $\left(P_{i}\right)$ was $45.13 \%$ (41.2\% to $47.1 \%)$. The averages of the observed $(\mathrm{Ho})$ and expected $(\mathrm{He})$ heterozygosities were 0.099 and 0.173 , respectively. $\mathrm{A}, \mathrm{Ae}, \mathrm{Ho}$ and $\mathrm{He}$ values did not show significant differences among bioclimatic zones $(P>0.05$, Tab. II). All bioclimatic zones were characterized by a significant deficit of heterozygotes $\left(F_{I S}>0, P<0.01\right)$.

Wright's $F$ statistics revealed significantly deficiencies of heterozygotes at species $\left(F_{I T}=0.657\right)$ and population $\left(F_{I S}=\right.$ 0.410 ) levels (Tab. III). For all loci, the average $F_{S T}$ was 0.414 , indicating a high genetic differentiation among populations (Tab. III). Significant differences in $F_{S T}$ values were observed among the majority of pairwise populations $(P<0.05$ and $P<0.001$ after 1000 permutations) (Tab. IV). The lowest $F_{S T}$ value (0.033) was observed among populations 3 and $4(60 \mathrm{~km}$ distant) and the highest one (0.679) was detected between populations 2 and 3 (140 km distant). Gene flow among populations was not significantly correlated with geographic distance (Mantel test, $r=-0.286, P=0.178>0.05$ ).

Within each ecological group, differentiation between populations was not significant $\left(0.032<F_{S T}<0.093, P>0.05\right.$ after 1000 permutations). However, a high differentiation was observed between the three ecological groups $\left(F_{S T}=0.445\right.$, $P<0.001)$.

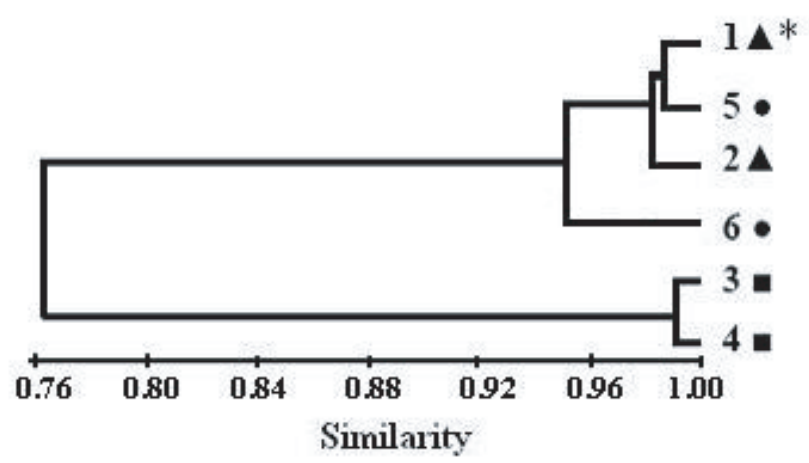

Figure 2. UPGMA dendrogram based on Nei's unbiased genetic similarity coefficients for the 6 populations of Myrtus communis. * Bioclimatic zone appartenance: $\boldsymbol{\Delta}$ lower humid, • sub-humid, $\boldsymbol{\square}$ upper semi-arid.

Nei's genetic similarity indices $(I)$ between pairs of populations were high $(0.701<I<0.991$; data available upon request). The average genetic identity for all populations was 0.86 . The dendrogram, constructed using these similarity coefficients, showed two distinct groups (Fig. 2). The first one includes populations 3 and 4 belonging to the upper semi-arid bioclimate. Populations 1, 2, 5 and 6 from the lower humid and the sub-humid zones clustered together in the second group.

\subsection{RAPD genetic diversity and differentiation}

For all individuals (45 over all populations), a total of 79 RAPD fragments were amplified (Tab. V). The number of bands varied from 9 (OPJ04) to 23 (OPJ20) according to the used primer. $88.61 \%$ of the amplified bands were polymorphic and $11.39 \%$ were scored for all individuals. Specific bands were revealed according to bioclimate. Bands $950 \mathrm{pb}$ (OPJ04), $320 \mathrm{pb}, 1500 \mathrm{pb}, 1800 \mathrm{pb}$ (OPJ08) and $1400 \mathrm{pb}, 1600 \mathrm{pb}$, $1800 \mathrm{pb}$ (OPJ20) were restricted to populations from the lower humid and the sub-humid. Bands $500 \mathrm{pb}, 550 \mathrm{pb}$ (OPJ10) and $320 \mathrm{pb}, 340 \mathrm{pb}, 360 \mathrm{pb}, 390 \mathrm{pb}, 650 \mathrm{pb}, 1300 \mathrm{pb}$ (OPJ20) were observed only in the upper semi-arid.

The percentage of polymorphic loci per primer $\left(P_{r}\right)$ ranged from 66.67 (OPJ08) to 100\% (OPJ04 and OPJ20). Average polymorphisms within populations ranged from $46.84 \%$ (population 6) to $56.96 \%$ (population 2), with a mean of $51.9 \%$ 
Table V. Selected RAPD primers, number of polymorphic bands and percentages of polymorphic loci $(\operatorname{Pr} \%)$ per primer.

\begin{tabular}{lrccc}
\hline Primer & Sequence & Polymorphic bands & Total bands & $P_{r} \%$ \\
\hline OPJ04 & 5'CCGAACACGG3' & 9 & 9 & 100 \\
OPJ08 & 5'CATACCGTGG3 & 10 & 15 & 66.67 \\
OPJ10 & 5'AAGCCCGAGG3' & 17 & 20 & 85 \\
OPJ12 & 5'GTCCCGTGGT3' & 11 & 12 & 23 \\
OPJ20 & 5'AAGCGGCCTC3' & 23 & 7.67 \\
Total bands and percentage of polymorphic bands & 70 & 79 & 88.61 \\
\hline
\end{tabular}

Table VI. Nested analysis of molecular variance (AMOVA) for the 45 individuals sampled from the 6 populations.

\begin{tabular}{|c|c|c|c|c|c|}
\hline Source of variation & d.f. & M.s. & Variance & $\%$ of total variance & $\Phi$-statistics \\
\hline Within populations & 39 & 0.098 & 0.0985 & $63.57^{* * *}$ & $\Phi_{\mathrm{ST}}=0.364^{* * *}$ \\
\hline Among bioclimatic zones & 2 & 0.895 & 0.0497 & $32.11^{* * *}$ & $\Phi_{\mathrm{CT}}=0.321^{* * *}$ \\
\hline
\end{tabular}

d.f.: Degree of freedom. M.s.: Mean squared. $*$ Significant at $P<0.05$, *** significant at $P<0.001$ (after 1000 permutations).

(Tab. II). Shannon's diversity index $\left(H^{\prime}\right)$ for all populations was $0.462\left(0.422<H^{\prime}<0.523\right)$ and its average within ecological groups was 0.521 . Populations from the sub-humid bioclimate showed the highest $P_{r}(64.56 \%)$ and $H^{\prime}(0.553)$ values (Tab. II). Differences for $H^{\prime}$ among bioclimatic zones were not significantly different (ANOVA test, $P=0.69>$ 0.05).

Pairwise $\Phi_{\mathrm{ST}}$ values calculated from AMOVA ranged from 0.017 (populations 1-2, $60 \mathrm{~km}$ distant) and 0.417 (populations 3-6, $102 \mathrm{~km}$ distant) (Tab. IV). Pairwise comparison of $\Phi_{\mathrm{ST}}$ values were all significant $(P<0.001)$ except among populations 1 and 2 (60 km distant) and populations 3 and $4(60 \mathrm{~km}$ distant). A significant differentiation was observed among populations $\left(\Phi_{\mathrm{ST}}=0.364, P<0.001\right)$ or among ecological groups $\left(\Phi_{\mathrm{CT}}=0.321, P<0.001\right)$. The Mantel test showed that gene flow and populations geographic distance were significantly correlated $(r=-0.63, P=0.018<0.05)$, indicating an isolation by distance. The differentiation among populations within ecological groups was also significant $\left(\Phi_{\mathrm{SC}}=0.064\right.$, $P<0.05)$.

AMOVA revealed that $63.57 \%$ of the total variation occurred within populations (Tab. VI). Variation among populations belonging to the same bioclimatic zone was lower $(4.32 \%)$ than that among the three ecological groups $(32.11 \%)$.

Nei and Li's similarity coefficients $(S)$ between individuals were substantial $(0.407<S<0.911)$ and the average genetic identity was 0.653 . The UPGMA dendrogram showed three distinct groups (Fig. 3). Within each group, populations clustered according to their bioclimatic and geographic locations.

\subsection{Combined isozyme and RAPD data analysis}

The UPGMA cluster, established on the basis of the combination of isozyme and RAPD data, showed three population groups corresponding to their bioclimatic zone appartenance
(Fig. 4). The cluster is comparable to that constructed through RAPD data.

Kendall's rank test performed on Shannon's diversity index $\left(H^{\prime}\right)$ and gene diversity $(H e)$ matrices was not significant ( $\tau=-0.333, P=0.348)$. However, a significant positive correlation was scored between $\Phi_{\mathrm{ST}}$ based on RAPD and $F_{S T}$ based on isozymes $(r=0.778, P=0.0027<0.05)$.

\section{DISCUSSION}

Tunisian Myrtus communis showed a high genetic variation within populations as estimated by both isozymic and RAPD markers. The high level of genetic variation could be explained by the species outcrossing breeding system and the persistence of multiple individuals through generations issued from large populations before fragmentation [22,57]. With RAPD markers, the observed genetic diversity was higher than that revealed by isozymes, as it has been reported in previous studies $[3,39,46]$. Differences could be attributed to (i) the inability of isozymes to detect variations that do not modify (or modify slightly) the amino-acids sequence, (ii) the high rate of mutation detected by RAPDs in both coding and noncoding genes $[1,55]$.

Isozyme data have revealed that the observed heterozygosity was lower than that expected under Hardy-Weinberg equilibrium. The deficit of heterozygotes was more important for populations belonging to the upper semi-arid bioclimate. The low size of these populations and the low rate of regenerated individuals from seeds are the main factors contributing to the deficiency of heterozygosity. This may lead to an increasing genetic drift [48].

A high genetic differentiation among populations and ecological groups was revealed either with isozymes and RAPDs. This differentiation might be the consequence of population isolation due to habitat destruction started since the last few decades [36,43]. Nevertheless, in this work, only RAPD markers showed an effect of isolation by distance in comparison 


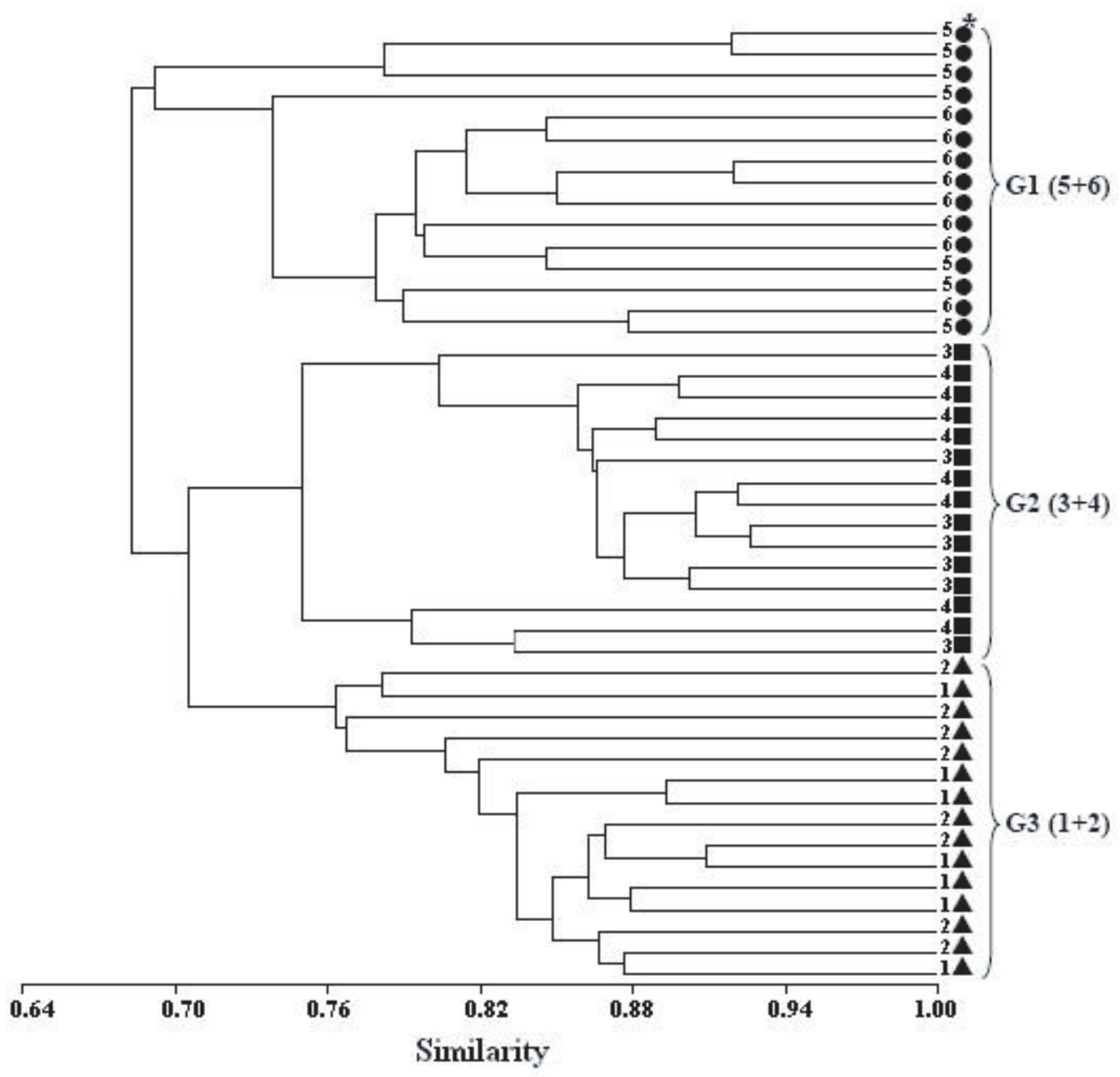

Figure 3. Dendrogram of the 45 individuals based on Nei's and Li's similarity coefficient. * Bioclimatic zone appartenance: $\Delta$ lower humid, • sub-humid, - upper semi-arid. 1, 2, 3, 4, 5 and 6: individuals belonging to populations $1,2,3,4,5$ and 6 , respectively $\mathrm{G} 1, \mathrm{G} 2$ and G3: group of populations.

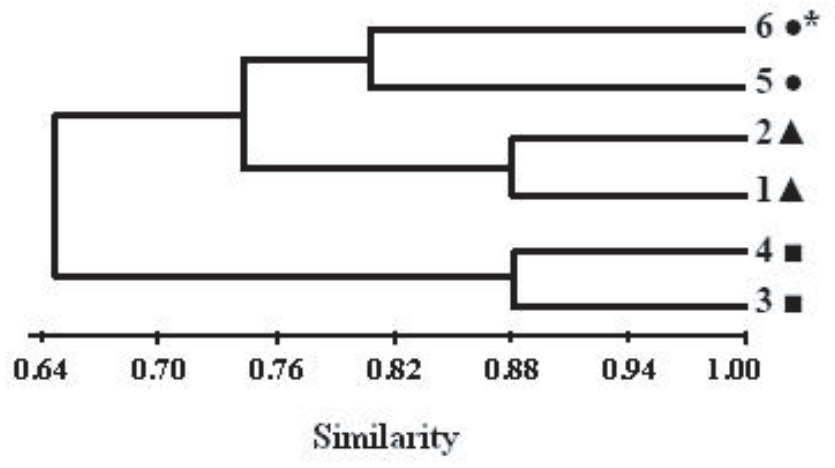

Figure 4. Dendrogram generated by genetic similarity between populations based on combined allele and RAPD band frequencies. * Population bioclimatic zone appartenance: $\Delta$ lower humid, • subhumid, $\mathbf{a p p e r}$ semi-arid.

with isozymes, although our previous study on 17 populations using isozymic markers has revealed a pattern of geographic isolation [32]. Thus, RAPD markers are more able than isozymes to reveal a more accurate effect of isolation by distance when population number is low [48].

Molecular $\left(\Phi_{\mathrm{ST}}\right)$ and isozyme $\left(F_{S T}\right)$ differentiation indices are significantly correlated $(r=0.778, P<0.05)$. The correlation between the two data sets suggests that the variation of the two markers may result from parallel evolutionary forces. However, RAPD markers revealed more bioclimatic differentiation than allozyme traits. These results differed from earlier polymorphism studies performed on fragmented populations of perennial species $[30,40,55]$. However, differentiation based on allozymes could be similar or higher than that based on RAPDs [3, 25], this may be attributed to (i) the higher number of analysed individuals per population in allozyme data that allows to an increasing allozyme differentiation [40], (ii) the dominance of RAPD markers, their biallelism and the interpretation of allele frequencies indirectly from RAPD phenotypes.

According to our estimates of genetic variation analysed by isozymes and RAPDs, the species showed a high genetic diversity within rather than among populations as it has been reported for outcrossing species $[16,22]$. So, efficient ex situ conservation programs may be mainly based on sampling 
individuals within populations intensively, in each ecological group, to catch the greatest gene diversity revealed by both methods. In situ conservation of populations should be conducted jointly with the restoration of biotopes. Favor artificial gene flow through transplantation between sites would be avoided. This could lead to a decreased fitness, disruption of locally adapted gene combinations and reduction of local variation $[11,14]$.

The divergent allele frequencies and particular alleles observed by both methods according to bioclimate call to appropriate preservation management. Populations of the subhumid, containing relatively high level of heterozygosity and sharing rare alleles, should be preserved first. Populations of the upper semi-arid were less genetically different. They should be protected mainly by valuable defence favouring individual regeneration. They are located at the South limit range of the species distributing area. Their low size could decrease their fitness through inbreeding depression. However, they showed specific alleles which could be related to local environment adaptation. So, conservation decisions about these populations should include additional adaptative parameters (morphological, physiological and edaphic characters).

Acknowledgements: The authors thank the Tunisian Ministry of Scientific Research and Technology and the National Institute of Applied Science and Technology for their financial support (Research grant 99/UR/09-10). The authors are also grateful to Professor Zaatour Nejib for helpful comments on earlier versions of the manuscript.

\section{REFERENCES}

[1] Aagaard J.E., Krutovskii K.V., Strauss S.H., RAPDs and allozymes exhibit similar levels of diversity and differentiation among populations and races of Douglas-fir, Heredity 81 (1998) 69-78.

[2] Agrimonti C., Bianchi R., Bianchi A. Ballero M., Poli F., Marmiroli N., Understanding biological conservation strategies: a molecular genetic approach to the case of myrtle (Myrtus communis L.) in two Italian regions: Sardinia and Calabria, Conserv. Genet. 8 (2007) 385-396.

[3] Bartish I.V., Garkava L.P., Rumpunen K., Nybom H., Phylogenetic relationships and differentiation among and within populations of Chaenomeles Lindl. (Rosaceae) estimated with RAPDs and isozymes, Theor. Appl. Genet. 101 (2000) 554-563.

[4] Baskin C.C., Baskin J.M., Seeds ecology, biogeography and evolution of dormancy and germination, Academic Press, London, 1998.

[5] Baytop T., Therapy with Medicinal Plants in Turkey - Past and Present, 2nd ed., Nobel Publishers, Istanbul, 1999.

[6] Bonnet E., de Peer Y.V., zt: a software tool for simple and partial Mantel tests, J. Stat. Soft. 7 (2002) 1-12.

[7] Clegg M.T., Allard R.W., Viability versus fecundity selection in the slender wild oat, Avena barbata L., Science 181 (1973) 667-668.

[8] Crawford D.J., Archibald J.K., Santos-Guerra A., Mort M.E., Allozyme diversity within and divergence among species of Tolpis (Asteraceae-Lactuceae) in the Canary Islands: systematic, evolutionary, and biogeographical implications, Am. J. Bot. 93 (2006) 656-664.

[9] Duke J.A., CRC Handbook of medicinal herbs, CRC Press, Boca Raton, Florida, 1988.
[10] Elfellah M.S., Akhter M.H., Khan M.T., Anti-hyperglycaemic effect of an extract of Myrtus communis in streptozotocin induced diabetes in mice, J. Ethnopharmacol. 11 (1984) 275-281.

[11] Ellstrand N.C., Elam D.R., Population genetic consequences of small population size: implications for plant conservation, Annu. Rev. Ecol. Syst. 24 (1993) 217-242.

[12] Emberger L., Une classification biogéographique des climats, Recherches et Travaux des Laboratoires de Géologie, Botanique et Zoologie, Faculté des Sciences Montpellier 7 (1966) 1-43.

[13] Excoffier L., Smouse P.E., Quattro J.M., Analysis of molecular variance inferred from metric distances among DNA haplotypes: application to human mitochondrial DNA restriction data, Genetics 131 (1992) 479-491.

[14] Fahselt D. The dangers of transplantation as a conservation technique, Nat. Areas J. 8 (1988) 238-244.

[15] Flamini G., Cioni P.L., Morelli I., Maccioni S., Baldini R., Phytochemical typologies in some populations of Myrtus communis L. on Caprione Promontory (East Liguria, Italy), Food Chem. 85 (2004) 599-604.

[16] Fournier N., Rigling A., Dobbertin M., Gugerli F., Faible différenciation génétique, à partir d'amplification aléatoire d'ADN polymorphe (RAPD), entre les types de pin sylvestre (Pinus sylvestris L.) d'altitude et de plaine dans les Alpes à climat continental, Ann. For. Sci. 63 (2006) 431-439.

[17] Frankel O.H., Brown A.H.D., Burdon J.J., The conservation of plant biodiversity, Cambridge University Press, Cambridge, 1995.

[18] Gérard P.R., Fernandez-M. J.F, Bertolino .P, Dufour J., Raquin C., Frascaria-Lacoste N., New insights in the recognition of the European ash species Fraxinus excelsior L. and Fraxinus angustifolia Vahl as useful tools for forest management, Ann. For. Sci. 63 (2006) 733-738.

[19] Godt M.J.W., Walker J., Hamrick J.L., Allozyme diversity in Macbridea alba (Lamiaceae), an endemic Florida Mint, J. Hered. 95 (2004) 244-249.

[20] Goodman M.M., Stuber C.W., Lee C.N., Johnson F.M., Genetic control of malate dehydrogenase isozymes in maize, Genetics 94 (1980) 153-158.

[21] Goudet J., FSTAT (version 2.9.3) a program to estimate and test gene diversities and fixation indices (2001) http://www.unil.ch/izea/softwares/fstat.html.

[22] Hamrick J.L., Godt M.J.W., Allozyme diversity in plant species, in: Brown A.H.D., Clegg M.T., Kahler A.L., Weir B.S. (Eds.) Plant population genetics, breeding and genetic resources, Sunderland, MA: Sinauer Associates, 1989, pp. 43-63.

[23] Heider B., Andersson M.S., Schultze-Kraft R., RAPD variation among North Vietnamese Flemingia macrophylla (Willd.) Kuntze ex Merr. accessions, Biodivers. Conserv. 16 (2007) 1617-1631.

[24] Huff D.R., Peakall R., Smouse P.E., RAPD variation within and among natural populations of outcrossing buffalograss (Buchlö̈ dactyloides (Nutt.) Engelm), Theor. Appl. Genet. 86 (1993) 927934.

[25] Isabel N., Beaulieu J., Bousquet J., Complete congruence between gene diversity estimates derived from genotypic data at enzyme and random amplified polymorphic DNA loci in black spruce, Proc. Natl. Acad. Sci. USA 92 (1995) 6369-6373.

[26] Karl S.A., Avise J.C., Balancing selection at allozyme loci in oysters: implications from nuclear RFLPs, Science 256 (1992) 100102.

[27] Kovach W.L., A Multivariate Statistical Package for Windows, version 3.1., Kovach Computing Services, Pentraeth, UK, 1999.

[28] Lee S.W., Ledig F.T., Johnson D.R., Genetic variation at allozyme and RAPD markers in Pinus longaeva (Pinaceae) of the White Mountains, California, Am. J. Bot. 89 (2002) 566-577. 
[29] Lodhi M.A., Ye G.-N., Weeden N.F., Reisch B.I., A simple and efficient method for DNA extraction from grapevine cultivars and Vitis species, Plant Mol. Biol. Rep. 12 (1994) 6-13.

[30] Lynch M., Milligan B.G., Analysis of population genetic structure with RAPD markers, Mol. Ecol. 3 (1994) 91-99.

[31] Mantel N., The detection of disease clustering and a generalized regression approach, Cancer Res. 27 (1967) 209-220.

[32] Messaoud C., Khoudja M.L., Boussaid M., Genetic diversity and structure of wild Tunisian Myrtus communis L. (Myrtaceae) populations, Genet. Resour. Crop Evol. 53 (2006) 407-417.

[33] Messaoud C., Zaouali Y., Ben Salah A., Khoudja M.L., Boussaid M., Myrtus communis in Tunisia: variability of the essential oil composition in natural populations, Flavour Frag. J. 20 (2005) 577582.

[34] Mulas M., Deidda P., Domestication of woody plants from Mediterranean maquis to promote new crops for mountain lands, Acta. Hortic. 457 (1998) 295-301.

[35] Mulas M., Francesconi A.H.D., Perinu B., Myrtle (Myrtus communis L.) as a new aromatic crop: cultivar selection, J. Herbs Spices Medicinal Plants 9 (2002) 127-131.

[36] Nabli M.A., Essai de synthèse sur la végétation et la phyto-écologie tunisiennes II et III : le milieu physique et la végétation, I.O.R., Tunisie, 1995.

[37] Nei M., Estimation of average heterozygosity and genetic distance from a small number of individuals, Genetics 89 (1978) 583-590.

[38] Nei M., Li W.H., Mathematical model for studying genetic variation in terms of restriction endonucleases, Proc. Natl. Acad. Sci. USA 76 (1979) 5269-5273.

[39] Oiki S., Kawahara T., Inoue K., Ohara M., Maki M., Random Amplified Polymorphic DNA (RAPD) variation among populations of the insular endemic plant Campanula microdonta (Campanulaceae), Ann. Bot. 87 (2001) 661-667.

[40] Peakall R., Smouse P.E., Huff D.R., Evolutionary implications of allozyme and RAPD variation in diploid populations of buffalograss (Buchloë dactyloides (Nutt.) Engelm), Mol. Ecol. 4 (1995) 135137.

[41] Pottier-Alapetite G., Flore de la Tunisie, Angiospermes dicotylédones. Apétales-Dialypétales, I.O.R, Tunisie, 1979.

[42] Renau-Morata B., Nebauer S.G., Sales E., Allainguillaume J., Caligari P., Segura J., Genetic diversity and structure of natural and managed populations of Cedrus atlantica (Pinaceae) assessed using random amplified polymorphic DNA, Am. J. Bot. 92 (2005) 875884.

[43] Schoenenberger A., La végétation forestière primitive et son état actuel, in: Nabli M.A. (Ed.), Essai de synthèse sur la végétation et la phyto-écologie tunisiennes. II et III : Le milieu physique et la végétation, I.O.R, Tunisie, 1995, pp. 209-278.
[44] Swofford D.L., Selander R.B., BIOSYS-1: a FORTRAN program for the comprehensive analysis of electrophoretic data in population genetics and systematics, J. Hered. 72 (1981) 281-283.

[45] Szmidt A.E., Wang X.-R., Lu M.-Z., Empirical assessment of allozyme and RAPD variation in Pinus sylvestris L. using haploid tissue analysis, Heredity 76 (1996) 412-420.

[46] Torres E., Iriondo J.M., Pérez C., Genetic structure of an endangered plant, Antirrhinum microphyllum (Scrophulariaceae): allozyme and RAPD analysis, Am. J. Bot. 90 (2003) 85-92.

[47] Tuberoso C. I. G., Barra A., Angioni A., Sarritzu E., Pirisi F.M., Chemical composition of volatiles in Sardinian myrtle (Myrtus communis L.) alcoholic extracts and essential oils, J Agric. Food. Chem. 54 (2006)1420-1426.

[48] Vandewoestijne S., Baguette M., The genetic structure of endangered populations in the Cranberry Fritillary, Boloria aquilonaris (Lepidoptera, Nymphalidae): RAPDs vs. allozymes, Heredity 89 (2002) 439-445.

[49] Wang Z.-F., Hamrick J.L., Godt M.J.W., High genetic diversity in Sarracenia leucophylla (Sarraceniaceae), a carnivorous wetland herb, J. Hered. 95 (2004) 234-243.

[50] Wang Z.-S., An S.-Q., Liu H., Leng X., Zheng J.-W., Liu Y.-H., Genetic structure of the endangered plant Neolitsea sericea (Lauraceae) from the Zhoushan Archipelago using RAPD markers, Ann. Bot. 95 (2005) 305-313.

[51] Weeden N.F., Wendel J.F., Genetics of plant isozymes, in: Soltis D.E., Soltis P.S. (Eds.), Isozymes in plant biology, Dioscorides Press, Portland, Oregon, USA, 1989, pp. 46-72.

[52] Weir B.S., Cockerham C.C., Estimating F-statistics for the analysis of population structure, Evolution 38 (1984) 1358-1370.

[53] Williams J.G.K., Kubelik A.R., Livak K.J., Rafalski J.A., Tingey S.V., DNA polymorphisms amplified by arbitrary primers are useful as genetic markers, Nucleic Acids Res. 18 (1990) 6531-6535.

[54] Wright S., The genetical structure of populations, Ann. Eugenics 15 (1951) 323-354.

[55] Wu J., Krutovskii K., Strauss S.H., Nuclear DNA diversity, population differentiation, and phylogenetic relationships in the California closed-cone pines based on RAPD and allozyme markers, Genome 42 (1999) 893-908.

[56] Yeh F.C., Boyle T.J.B., Population genetic analysis of codominant and dominant markers and quantitative traits, Belg. J. Bot. 129 (1997) 157.

[57] Young A., Boyle T., Brown T., The population genetic consequences of habitat fragmentation for plants, Trends Ecol. Evol. 11 (1996) 413-418. 